\title{
Unbuilt Anxieties: Infrastructure Projects, Transnational Conflict in the South China/East Sea, and Vietnamese Statehood
}

\section{Ken MacLean}

\begin{abstract}
The conflicts shaping territorial claims and counter-claims to overlapping areas of the South China Sea threatens to significantly damage Sino-Vietnamese relations, destabilize regional security arrangements, and alter the geopolitical status quo. The governments of both countries routinely invoke historical documents, commission scientific studies, and cite legal principles to justify their competing claims in the maritime region and the resources contained therein. The role different types of energy infrastructure play in the state-level disputes have received little attention, however. This essay addresses this oversight. In it, I foreground the complex ways not yet built infrastructure affect Sino-Vietnamese relations as well as our theoretical understanding of "the state", especially with regard to Vietnam. Not yet built infrastructure refers to more than the assemblage of things that will be built in the future to power the economy, such as oil rigs, natural gas pipelines, and refineries. The concept also includes the ideological positions that presuppose the materialization of blueprint plans in physical form, i.e., the broader goals such infrastructure is meant to achieve. Towards this end, the article focuses on how state actors and their proxies conceptualize the likely impacts not yet built infrastructure will have upon their respective interests once construction is completed. The case study highlights how the need for energy security strengthens national security at some moments, weakens it at others, and both at still others.
\end{abstract}

KEYWORDS: South China Sea, Vietnam, China, Infrastructure, Conflict

$\mathrm{T}$ HE ETHNOGRAPHIC LITERATURE ON infrastructure has expanded significantly over the past fifteen years. This growing body of critical work is part of a broader "anti-anthropocentric" turn in the human sciences (Boyer 2014: 318). The conceptual movements associated with this turn are theoretically and methodologically diverse. But most of them remain philosophically committed to the idea that non-human objects possess agency and thus have the capacity to participate in social networks on material and semiotic levels simultaneously (Coole and Frost 2010). Infrastructure possesses a "peculiar ontology" as a result (Larkin 2014: 329). Highways, sewer systems, and power grids, to offer three common examples, facilitate the circulation of matter that our everyday lives depend upon. However, our understanding of and interest in such infrastructure, 
Larkin points out, is normally "displaced" (i.e., supplanted) by what these networks enable to move through them - in this instance: vehicles, water, and electricity, respectively. When large-scale construction begins, failures occur, and major repair starts infrastructure returns to the foreground as the subject of significant interest and concern (Anand 2012). It is during these moments when the "collective meaning" and "material orderings of society" (Coleman 2014: 457) are most visibly made and remade. The territorial disputes in the South China/East Sea exemplify both processes. ${ }^{1}$ Yet, the role different types of infrastructure, especially not yet built infrastructure, play in them has received almost no attention. Consequently, our understanding of how the People's Republic of China (PRC) and the Social Republic of Vietnam (SRV) engage with one another offshore remains incomplete.

The concept of not yet built infrastructure encompasses more than the material elements that, when assembled together, constitute an object (e.g. the pipes, fittings, and girders that help form an oil rig). Not yet built infrastructure also includes the ideological positions that presuppose the materialization of blueprint plans in physical form-that is, the why behind the what (Collier and Lakoff 2008). Consequently, infrastructure is a type of "promissory note" because it promises a "future benefit," one that is typically embedded in narratives of progress (Hetherington 2014: 196). Infrastructure has a temporal as well as a spatial component for this reason. In this essay, I focus on how state actors and their proxies calculate the likely impacts not yet built infrastructure will have, if constructed, upon their respective security interests. I italicize "will" for two reasons.

First, anxieties surrounding not yet built infrastructure in the South China/ East Sea are oriented towards possible "futures." This temporal orientation sharply contrasts with the historical and legal arguments claimant states in the region make, which rely heavily upon archival materials and legal precedent, respectively (Buszynski and Roberts 2014). (These states include Brunei, Indonesia, Malaysia, the Philippines and Taiwan, in addition to Vietnam and China.) Such "evidence," much of it drawn from the pre-colonial and colonial periods is problematic. State sovereignty, as a legal concept, emerged out European political theory and practice in the seventeenth century. But its key principles (exclusive territorial control, noninterference in a country's domestic affairs, and equality in international law) did not become institutionalized "globally" until the mid-twentieth century. The highly selective and often anachronistic mobilization of these documents, maps, and case law by state-recognized experts, as well as well-respected amateur pundits, while fascinating and deserving of close study, contribute to the proliferation of different "national" pasts, and thus conflicting

\footnotetext{
${ }^{1}$ Several governments reject the prefix "South China" when referring to the maritime region on the grounds that it reinforces the People's Republic of China's territorial claims. Vietnamese speakers, for example, call the region the East Sea. I use the hybrid - South China/East Sea for this reason.
} 
histories of the present (MacLean 2013). Careful analysis of the role imagined futures play in the territorial disputes provides insights into what has been heretofore overlooked about these contested histories: state territorialization through not yet built infrastructure.

Second, the word "will" has embedded within it assumptions about causality, namely, the construction of " $\mathrm{x}$ " will result in " $y$," which is why state-authorized preemptive action as a precautionary measure plays such a key role in the territorial disputes. The central goal of preemptive action is to prevent undesired events from occurring and to mitigate aspects of them when they do. Preemptive action offshore thus serves as a way to "organize uncertainty into risk that can be managed" (Power 2007: 6). Such action is a key feature of the South China/East Sea conflicts for several reasons. The region is one of the world's largest bodies of water after the five oceans, covering approximately 3.5 million square kilometers. It is also the world's fourth most productive fishery and it is potentially energyrich. In addition, the region is one of the busiest maritime zones in the world; approximately half the goods sent globally by sea pass through the region en route to their final destination (Nguyễn Hồng Thảo 2005: 26). These features ensure a wide range of non-local actors take a strategic interest in the outcome of these disputes as well (Bateman and Emmers 2009: 7-57), especially as the PRC claims "historic rights" to approximately eighty-percent of the South China/East Sea - visually represented on its official maps as a nine-dashed U-shaped line (Keyuan 2012). The validity of the PRC's claims is not supported legally (Dupuy and Dupuy 2013). Nevertheless, the PRC, as well as several other states, continue to materialize their claims through extra-legal means, which is why not yet built infrastructure is shaping possible futures in the sea, including aspects of Vietnamese statehood.

"Anti-access and area denial (A2AD) strategies" provide an example. A2AD is the new security term for an old idea, notes Le Mière (2012). Traditionally, he explains, "A2AD strategies are designed to avoid decisive engagement with the opponent, utilizing asymmetrical or stand-off capabilities to weaken and harass [stronger] adversaries" (1-2). These strategies rely upon a range of fixed and mobile elements. "Long-range" intelligence platforms and weapons systems (e.g. satellite technology and GPS-guided munitions) are designed to deter an adversary from entering an area and, if this occurs, "short-range" capabilities (e.g. air defense, submarines, and mines) can be deployed to limit freedom of movement within it. A2AD is a spatially defensive approach to the national security challenges a stronger military force poses for a weaker one for this reason. A2AD is relational as well. United States military efforts to "pivot" (i.e. rebalance) towards the Asia-Pacific region have prompted the Chinese military to dramatically upgrade its A2AD capabilities (Buszynksi 2012: 145-148). These upgrades have led many neighboring states to do the same in response to the threat they perceive the PRC's massive investment in its defense resources poses to their own national security. Vietnamese military spending, for instance, surged 270 
percent, averaging 2.25 percent of GDP, between 2004-2013 (Indo-Pacific Review 2014). The proliferation of A2AD “defense procurement rivalries" (Le Mière 2012: 1) thus threatens the security status quo across the entire Pacific littoral (McDevitt, Fravel, and Stern 2013).

This essay is comprised of five interrelated sections. Each of them illustrates how not yet built infrastructure shapes Sino-Vietnamese territorial disputes in the South China/East Sea and the ongoing reconstruction of Vietnamese statehood. The first section describes the quasi-violent conflict that occurred in 2014 when a PRC oil rig, a form of "mobile national territory" (Murphy 2013: 110-114), began drilling test wells in waters the SRV claims as it own. Next, I detail the violent anti-China protests that took place onshore in Vietnam, largely in response to the purported violation of the country's sovereignty. The riots destroyed existing economic infrastructure, but also created "communities of aspiration" (Hetherington 2014: 198) that fueled articulations of Vietnamese maritime nationalism. The third section provides an overview of the planned, but not yet built infrastructure offshore and the forms of preemptive action linked to them. These plans are driving the current construction of support infrastructure on islands, rocks, and other features to support energy exploration and extraction in the future, an issue I discuss in the fourth section. The essay concludes with a broader discussion of these processes, which strengthens Vietnamese national security at some moments, weakens it at others, and both outcomes at still others.

\section{Floating Infrastructure}

The tugboats slowed and the massive Haiyang Shiyou-981 rig (HYSY-981) gradually came to a halt on May $2^{\text {nd }}, 2014$. Completed in 2011, at an estimated cost of US\$ 1 billion, the state-owned and operated HYSY-981 is the PRC's first deepwater semi-submersible drilling unit. Once positioned, the unit is capable of operating in waters as deep as 3,000 meters and to drill to the depth of 10,000 meters (Xu Liangbin, Jiang Shiquan, and Zhuo Jianliang 2013). The HYSY-981 anchored itself 120 nautical miles east of Vietnam's Ly Son Island and 180 nautical miles south of China's Hainan Island. The two islands are the two nearest undisputed natural features in the region. Under the terms of the 1993 United Nations Law of the Sea (UNCLOS), each island generates its own Exclusive Economic Zone (EEZ), which extends 200 nautical miles from their maritime baselines (United Nation 1993: 40-49). Their respective EEZs unavoidably overlap due to the geographic proximity of these features to one another. This overlap, which is only one of many in the South China/East Sea, has important legal implications. An EEZ is made up of the surface, the seabed, and the water column located between them. These elements, because they are interconnected, give rise to three legal issues: 1) the sovereign rights of the coastal State, 2) its jurisdiction, and 3) rights of other States. Under UNCLOS, a coastal State has 
sovereign rights over the natural resources within its EEZ; it can exercise jurisdiction over other activities; but it must respect the rights of other States to freedom of navigation (1993: 33-35).

The SRV immediately filed an official protest, arguing that the area was located not only well within its EEZ, but anchored over the country's continental shelf as well. Under UNCLOS, a coastal State's sovereign rights are exclusive, meaning that the exploration and exploitation of a continental shelf's resources (most often oil and gas fields) are forbidden without its express consent (1993: 49-51). Consequently, the rig's crew, which conducted seismic surveys and drilled test wells for more than two months, was in violation of international law from the SRV's perspective (Socialist Republic of Vietnam 2014a). The PRC challenged this position on three grounds. First, the UN Commission on the Limits of the Continental Shelf had not yet verified the technical accuracy of the SRV hydro-geological maps. Second, the waters separating China and Vietnam in this area are not officially delimited. Third, HYSY-981 was located inside the contiguous zone of Triton Island, which the PRC administers, making its operations legal under UNCLOS in its view. (Both Taiwan and Vietnam also claim the island.) Therefore, Vietnamese efforts to force HYSY981, a state proxy, to leave the area constituted a "serious infringement" of the PRC's sovereignty, sovereign rights, and jurisdiction, in addition to "relevant international laws," according to official spokespersons (People's Republic of China 2014). The diplomatic standoff quickly became the most serious bilateral crisis since 1988, when a skirmish over the Johnson South Reef, in the Spratly Archipelago, left more than seventy Vietnamese soldiers dead.

In the media wars that followed, the SRV's Ministry of Foreign Affairs regularly denounced Chinese "intrusions" into its territory, while the PRC's Ministry of Foreign Affairs decried Vietnamese "provocations." Both governments encouraged foreign and domestic reporters to document the encounters and the images they disseminated, often re-presented by third parties online in highly partisan ways, confused rather than clarified the situation. Some aspects of the confrontation are clear, however, and they highlight the roles floating infrastructure played in it.

The SRV dispatched twenty-nine Coast Guard and surveillance ships belonging to the Fisheries Bureau of the Ministry of Agriculture and Development to prevent the rig from establishing a fixed position from which it could operate. The number of Vietnamese vessels quickly grew to more than sixty, the majority of them being independently owned wooden-hulled fishing boats, to support the government's A2AD area-denial strategy. Their goal was to prevent the rig from gathering the data the PRC would need to determine whether a permanent offshore platform should be built in the future. But the Vietnamese ad hoc fleet was badly outmatched by the Chinese flotilla. The number of its escort and service vessels ranged, on average, from seventy to eighty in number, and included six warships, approximately three-dozen Coast Guard and marine surveillance 
vessels, several dozen iron-clad fishing boats, as well as surveillance planes and helicopters (SRV 2014a: 1-3). The Vietnamese government submitted a series of formal letters of protest to the Chinese Ambassador and high-ranking officials representing its Ministry of Foreign Affairs, Ministry of Defense, National Border Committee, and General Office of the State Council while the events at sea were unfolding. The General Director of PetroVietnam, a state-owned enterprise, wrote the China National Offshore Oil Corporation (CNOOC), its counterpart, demanding that the rig's crew immediately suspend its activities and the flotilla withdraw from the area.

The letters issued in response and the meetings held did not prevent clashes at sea (Shoji 2014: 1). Official Vietnamese sources claim that the Chinese fleet established three concentric rings to cordon off the rig, and that Chinese vessels repeated rammed Vietnamese ones, sprayed their crews with water cannons, and eventually sank one boat to prevent them from surrounding the rig (SRV 2014a). Video footage, uploaded to YouTube, documented some of these events. The Chinese Foreign Ministry disagreed with the interpretation, however, stating that images actually showed the escort vessels acting in self-defense, adding that Vietnamese "frogmen and other underwater agents" had placed "fishing nets and floating objects" in the water to damage the Chinese ships' propellers (PRC 2014). In mid-July, HYSY-981 finally withdrew from the disputed area.

Such confrontations regularly occur, though on a much smaller scale, typically peaking during the annual ten-week fishing ban the PRC unilaterally imposes on most of the South China/East Sea. (In 2015, the HYSY-981 returned to the disputed area during the ban and completed a test well.) Chinese naval vessels routinely harass non-Chinese fishermen during the ban, damage their boats and equipment, and, occasionally, detain them until their families pay exorbitant fines. Public protests against the seasonal fishing ban and other forms of Chinese territorial encroachment (both real and imagined) have become common, especially in the SRV and the Philippines, dramatically strengthening popular expressions of maritime nationalism in the process, both in the streets and online. Government-sponsored exhibitions, featuring historical "evidence" of sovereignty (documents, photographs, and maps), further reinforce such feelings (MacLean 2014: 382). Maritime nationalism, fueled by state-managed media, is a significant issue in China as well, though it has different causesthe dominant one being "national humiliation" narratives, which graphically depict the political, economic, and cultural anxieties caused by the transformation of the Qing Empire into the Republic of China. The result is a paradox, as the different cartographic genres present two radically different versions of the country's geo-body-one set depicted a contracting one, the other an expanding China. "Reclaiming" the South China/East Sea is thus widely regarded in China as being not only essential to the country's national interests, but part of the broader process of reestablishing its "rightful place" in the global order of things (Callahan 2009). Many Vietnamese strongly disagree. 


\section{INFrastructure Destroyed}

"Infrastructure," Hetherington observes, "marks the moment at which people become enrolled in a particular community of aspiration" (2014: 198). Such a community may define itself in opposition to another. Anti-China protests began in Hanoi and several of the country's other major cities on May $11^{\text {th }}$, nine days after the HYSY-981 dropped anchor. The planned protests, which were of unprecedented size, spread nationwide but primarily in southern Vietnam, where most of the country's industrial parks are located and Chineseowned factories are concentrated. The language appearing on banners and employed in speeches was remarkably consistent, and it emphasized the territorial integrity of the "nation" (e.g. The Paracels and Spratlys are Vietnam) as well as China's violation of it (Down with Chinese aggression and China get the hell out of Vietnam's islands). Protests by overseas Vietnamese took place in North America, Europe, and elsewhere in Asia, and the discourse used was similar, but geographically broader in that protestors framed the crisis as a specific instance of a larger one (e.g. China has no part in the Southeast Asia Sea and The world supports Vietnam and the Philippines).

Significantly, the protests were not simply about the rig and the deployment of Chinese naval forces to support it. Labor conditions in Chinese export processing zones were an issue in many places as well (Hạ Mai 2014). Organizers of several of the initial demonstrations told foreign reporters that they were using the dispute to protest the government's long-history of acceding to their Chinese counterpart's policy demands, including those related to the South China/East Sea, and the repression of those people who publicly speak out about it (Dou and Paddock 2014). People who hold this view commonly accuse members of the Party-state of "selling the country" by granting territorial concessions and/or making deals that benefit them personally at the expense of the "nation" (MacLean 2008). Security forces arrested nearly two-dozen "dissidents" immediately prior to the second planned demonstration in Hanoi and Ho Chi Minh City, giving credence to these claims.

This crackdown was part of a much broader one. The Vietnamese government initially tolerated the mass demonstrations, provided that they remained "legitimate," by which it meant responsible and law-abiding. The qualified support was indicative of tensions among high-ranking Party/state officals with regard to the standoff offshore. Some high-ranking Party/state officials encouraged the protests as a way to pressure the government to take a more aggressive foreign policy stance. Other officials urged restraint, and stressed that further diplomacy would resolve the dispute (Socialist Republic of Vietnam 2014b). Large-scale strikes turned into violent riots in several provinces on May 13th and quickly sidelined this disagreement. Workers reportedly chanted, "Protecting the workplace means protecting the Spratly and Paracel Islands" from inside their barricades. Others yelled traditional political slogans: Long Live 
Vietnam. Still others shouted more nationalistic ones: I Love the Nation and Oppose China. Then, for reasons that are not yet clear, large numbers of people went on to damage, loot, or destroy factories, 351 of them in Binh Duong Province alone. Strikingly, a significant percentage of the factories were not in fact Chinese, but Taiwanese, South Korean, Japanese, and Singaporeanowned ones, which are among Vietnam's top foreign investors. Tragically, perhaps as many as twenty-one Chinese workers died, dozens more were injured, and the Chinese government decided to evacuate an estimated 3,000 Chinese nationals via chartered planes and ships in response, while an unknown number fled overland to Cambodia on their own (Tuẩn Khanh 2014).

Questions remain as to why the rioters attacked non-Chinese-owned factories. Rumors, as well as some analysts, assert that Vietnamese Communist Party elites who seek to accommodate China were, if not behind the riots, used them to convey two messages to Party elites who advocate for a more confrontational approach to the territorial disputes (Abuza 2014). First, media accounts that stressed the indiscriminate nature of the violence made it clear that growing anti-Chinese-oriented nationalism, if not suppressed, would threaten these country's financial investments in Vietnam's export sector, i.e., prevent the construction of future economic infrastructure. Second, these same accounts also cited the severity and scale of the violence to justify the nationwide security crackdown to "restore order" that followed (Huong Le Thu 2014: 6-7). Both narratives have merit. The Chinese government did order its state-owned enterprises to suspend further investment in response to the riots; foreign governments that initially expressed support for the Vietnamese government's position on the HYSY-981 rig denounced the violence; and Vietnamese security forces arrested approximately 1,400 people in connection with the riots, as well as dozens of activists who advocated more decisive action in the South China/East Sea to counter China's alleged violation of the country's sovereignty (Roberts 2014). Large-scale public demonstrations in major cities ended shortly thereafter, though Chinese demands for compensation have not. The destruction of existing infrastructure of economic production onshore had little impact on infrastructure in preparation offshore, however.

\section{Infrastructure in Preparation}

The attacks on the factories and the suppression of public activism are closely connected with the perceived security threats not yet built infrastructure pose to de jure claims in maritime contexts. In the South China/East Sea these threats are concentric in nature because the construction of site-specific infrastructure can legally extend a State's sovereignty and different forms of jurisdiction into successively larger circles (territorial seas, contiguous zones, and exclusive economic zones, respectively) where it previously had none, if key 
UNCLOS provisions are met. Such infrastructure thus can generate different kinds of "national" territory and thus new understandings of the "nation's" geobody (Winichakul 1997) in the process, if only in the eyes of those actors that claim it.

The Paracel and Spratly Archipelagoes, which are at the center of the SinoVietnamese territorial disputes for this reason, consist of approximately 650 reefs, atolls, cays, rocks, islets, and islands, many of the unnamed. The ontological and thus legal status of these features is not clear, however (Gjetnes 2010). Following nine years of negotiations, UNCLOS III was only able to adopt a single provision concerning islands, the two key elements of which state: "An island is a naturally formed area of land, surrounded by water, which is above water at high tide," and "Rocks that cannot sustain human habitation or economic life of their own shall have no exclusive economic zone or continental shelf" (1993: 65) The definition is problematic on a number of levels. Most obviously, it does not address the legal status of insular formations, which may have one or more islands among them. Consequently, it is unclear which formations (or parts of them) are entitled to a territorial sea (12 nm), contiguous zone (24 nm), EEZ (200 nm), and continental shelf (Elferink 2001). Moreover, the solution to this problem, the proper scientific delimitation of these natural formations, cannot occur until the overarching one, the political disputes over sovereignty, is resolved.

In the meantime, nearly all of the claimant states employ a range of sovereignty- and jurisdictional-producing practices to advance their respective interests. The construction of military facilities to establish a permanent presence on a feature, a key element of what constitutes an "island," is the most direct tactic used. Indirect tactics include dispatching soldiers to formations to conduct patrols at regular intervals on a daily basis, anchoring ships over submerged features, or visually monitoring from a directly occupied one to demonstrate that a nearby one is also "occupied." Such practices are contingent upon the ongoing construction of these facilities, which satellite maps and surveillance planes can document in real time (Hardy and O'Conner 2014). The state-sponsored occupation of these features, however, violates the 2002 Declaration on the Conduct of Parties in the South China Sea. Article 5 requires all Parties "to exercise self-restraint in the conduct of activities that would complicate or escalate disputes and affect peace and stability including, among others, refraining from action of inhabiting on the presently uninhabited islands, reefs, shoals, cays, and other features and to handle their differences in a constructive manner" (ASEAN and PRC 2002). The SRV has employed this tactic to occupy six islands, seventeen reefs, and three banks in the Spratly Archipelago, while the PRC has secured nine reefs in the same area as well as all the features located in the Paracel Archipelago (MacLean 2014: 378).

Both countries, but especially the PRC, have recently begun to carry out large-scale land reclamation projects to enlarge recognized islands as well as rocks and other features into "islands" that can be permanently occupied and 
strategic infrastructure later built (Beckman 2014). Current estimates place the total terra-formed at thirteen square kilometers (Larson 2015: 1434). The terraforming projects not only produce the geological infrastructure (i.e. land) needed to support the construction of new military facilities, they enhance the PRC's A2AD capabilities vis-à-vis the United States and materialize the Chinese government's territorial claims. For example, satellite imagery, taken by Airbus Defense and Space, a European Union-based company, revealed a massive terraforming project on the Fiery Cross Reef, which the Philippines, Vietnam, and Taiwan also claim (Hardy and O'Conner 2014; Jennings 2014). The 3,000-meter long by 300-meter wide airstrip, when completed, will become the PRC's first in the Spratly Archipelago, establishing military parity with the Philippines, Vietnam, Taiwan, and Malaysia. The China Ship Scientific Research Center, which is part of the China Shipbuilding Industry Corporation, has also developed large, rectangular docks with bridge attachments to anchor them to islands, reefs, and other features the PRC's military wishes to claim. According to one research center official, the docks will be able to accommodate ships weighing up to 1,000 tones and function as maintenance and repair stations for vessels that supply food to troops stationed on them. Power generators, fresh water storage and supply, as well as desalinization equipment will provide for their other daily needs. These docks, the source continued, will thus make it possible for the navy to quickly build settlements on remote islands, rocks, and reefs in the future (Want China Times 2014), making them force multipliers in infrastructural form.

\section{Proxy Infrastructure}

The Vietnamese Prime Minister ratified the country's national energy development strategy in late 2007. The document outlines the government's priorities in this sector through 2020 and envisions what it will look like by 2050 . Not surprisingly, the strategy calls for source diversification (hydropower, renewables, biomass, etc.) and greater emphasis on conservation to meet the broader objective of “establishing ‘open’ national energy security” in order to develop an "independent, self-supporting economy” (Nguyễn Tấn Dũng 2007). While the government's overall goal is to reduce hydrocarbon dependence, increasing strategic oil-product reserves remains a key element of the current strategy. Doing so will be challenging.

PetroVietnam forecasts reveal that oil production in the Bach Ho field, the country's largest proven reserve, peaked in 2001, and that the number of thousand barrels extracted per day is now rapidly declining (Hai Tien Le 2012: 6). Satellite fields, especially in the Nam Con Son and Cuu Long basins, have also peaked and their totals are dropping as well (2012:6). PetroVietnam data now indicates that Vietnam will have shifted from being a net exporter of crude oil to a net importer at the end of 2015. PetroVietnam projections further project the 
gap between production and consumption will escalate rapidly thereafter, with domestic demand expected to exceed national supply by a ratio of 8:1 in 2025 . PetroVietnam is presently purchasing crude oil from Azerbaijan to maintain a stable supply, and it plans to source additional fuel from Kuwait beginning in 2017 (U.S. Energy Information Administration 2014). PetroVietnam's strategic response to this situation also exhibits concentric spatial dimensions: 1) the upgrade and construction of onshore refineries; 2) the upgrade and construction of offshore infrastructure, specifically, pipelines and distribution networks; and 3) deep-water exploration for new fields out to the edge of its continental shelf. This strategy requires significant foreign expertise and investment; it is also consistent with the country's broader A2AD strategy. The SRV seeks to internationalize support for its territorial claims through joint-venture profit-sharing agreements with other Asian, European, and North American companies and, more importantly, their foreign state-owned enterprises, raising the diplomatic costs of the PRC "invading" oil and gas blocks where they operate in the process.

Onshore, recent construction has significantly expanded production at Dung Quat, the country's first refinery. The Japan Bank for International Cooperation is financing seventy percent of the construction costs for the country's second refinery in the Nghi Son economic zone, Thanh Hoa Province, the eventual destination for Kuwait Petroleum International's crude oil. When completed, this refinery will supply north and north-central Vietnam. More refineries, which will also attract a significant amount of foreign investment, are in the planning stages. Offshore, five major pipelines are currently in operation. These pipelines are connected to distribution systems, which compress the extracted dry gas and then convey it under high pressure via a network of smaller submarine pipelines to landfall stations, primarily in the south. Nam Con Son I, located southeast of Ho Chi Minh City, is the largest pipeline (26 inches/400 kilometers). The Nam Con Son II pipeline is currently under construction. When completed, at an estimated cost of US $\$ 1.3$ billion, it will dramatically expand the existing distribution network (Nguyễn Tấn Dũng 2007), further materializing the country’s maritime geobody.

Offshore, both the SRV and the PRC have employed a number of sovereignty producing practices to advance their territorial claims and to challenge those made by the other over the past three decades. In 1992, the PRC granted a concession to Crestone Energy Corporation, a U.S. energy company, in Vietnam's EEZ, which is more than 650 nautical miles from China's mainland coast. The Chinese government defended the move, claiming that it has "historic rights" over the area, as the concession block falls within the country's controversial U-shaped line. The Vietnamese navy dispatched ships to prevent Chinese vessels from surveying the area, and PetroVietnam transported one of its own rigs "to occupy" the site. The Chinese vessels proceeded to blockade the rig in order to prevent Vietnamese ones from transporting supplies to it. Both parties later withdrew, and Crestone decided not to pursue exploration further 
(The Economist 2015). Two years later, PetroVietnam awarded a concession in the same area to the same U.S. energy company, now known as Harvest Natural Resources. The company eventually withdrew from the deal because of PRC objections. In 2006, Chevron signed a deal with Malaysia's state-owned oil company, Petronas, to explore a different part of Vietnam's EEZ for hydrocarbons. Again, the Chinese government issued a formal complaint to Chevron and Petronas on the grounds that further exploration would violate the country's sovereignty. Chevron closed its operations the following year (Cunningham 2014). Chevron signed a thirty-year production-sharing contract with the China National Petroleum Corporation to develop natural gas fields in the central part of the country shortly afterwards (Chevron 2007), suggesting that a quid pro quo agreement contributed to the U.S. company's decision to withdraw. More recently, Exxon Mobil discovered oil and gas in Block 118, off of Vietnam's central coast, well within the country's EEZ, in 2011. Once again, the Chinese government publicly warned foreign energy companies from further exploration of the area. Then, in mid-2012, China's CNOOC issued an invitation for international bids for nine blocks with a total area of more than 160 million square kilometers. The concessions overlapped with those parts of blocks 118 and 119 that fell within the PRC's U-shaped line, and no Vietnamese joint-venture oil and gas production has taken place since then (PetroVietnam News 2012).

These examples highlight some of the strategies the two governments and their state-owned energy enterprises (as proxies) routinely use to contest one another's not yet built joint venture projects. These strategies include the invocation of legal rights, quasi-non-violent confrontations at sea, counter-concessions to the same disputed block, and threats of economic retaliation. The HYSY981 controversy is notable because it exhibited elements of all of these strategies. The previously described confrontation at sea took place on the border of Vietnamese blocks 142 and 143, which are adjacent to blocks 118 and 119. The arrival of HYSY-981 in this area confirmed what many analysts had long suspected. Two years earlier, at the ceremony celebrating the rig's maiden voyage, CNOOC Chairman Wang Yilin addressed a large crowd of invited guests, which included representatives from key government ministries and the armed forces. During his speech, the Chairman proudly declared that the HYSY-981 was a new type of "mobile national territory" and, as such, would serve as our "strategic weapon" for developing the country's offshore oil and gas industry (Murphy 2013: 110-114). The statement, which Vietnamese-language commentators translated verbatim and disseminated widely, is striking on at least two levels.

Politically, CNOOC is a state-owned enterprise and, therefore, plays no official role in shaping foreign policy. But CNOOC is also a state-directed enterprise, and the statements, which other well-placed individuals have made before him, confuses rather than clarifies the Chinese government's position on such infrastructure. International law does not recognize drilling platforms as sovereign territory. Yet, as maritime expert Martin Murphy explains, doing so creates an 
"ambiguous political-legal aura of authority and control," which may in fact be the government's intended goal given that part of the blocks fall within the country's controversial U-shaped line (Murphy 2013: 111). Economically, large stateowned enterprises as well as provincial governments often pursue their own interests, and their CEO's actions do not always coincide with those of the central government. Some CEOs have earned political promotions by advancing corporate interests in ways that successfully coincide with those of the PRC (Downs 2014: 6). The deployment of the HYSY-981 is certainly consistent with actions central- and provincial-level actors have taken over the past several years. And the size the flotilla that accompanied it indicates that there was a high-degree of inter-agency cooperation and, thus, government support for the provocative move (Storey 2014: 3). The move, an aggressive form of A2AD, a strategic form of national defense, provides insights into the state of Sino-Vietnamese relations.

\section{A2AD REVISITED}

The HYSY-981 rig withdrew on July $15^{\text {th }}, 2014$, one month earlier than scheduled. A range of explanations quickly began to circulate online speculating why it did. Chinese sources emphasized success and the weather. The state-owned China Petroleum Corporation announced that the surveys and test wells had found "signs of oil and gas," consequently further exploration was not needed at this time. A "super" typhoon was also entering the region, and weather models predicated it would reach Hainan Island approximately three days later. The HYSY-981, while not in its direct path, would experience very high winds and rough seas, so moving to shallower water would protect the rig and the boats (Thayer 2014). The post-typhoon return of the rig to undisputed Chinese territory raised questions online, however. Some of these questions were technical. Was the rig actually able to withstand strong storms and remain in deep water during typhoon season as CNOOC asserts? If not, would this limitation constrain CNOOC's ability to drill in deep water areas that the SRV claims? (PetroVietnam currently lacks such capacity, and it is partnering with Gazprom, a Russian energy company, to develop it.) Other questions were diplomatic in nature and revolved around whether the withdrawal was a face-saving measure or a tactical one designed to de-escalate the crisis after having established precedent. Regardless of the answer, the Chinese government, using CNOOC as a proxy, clearly made a point: its state-owned energy companies are not only able to drill in deep waters inside Vietnam's EEZ, but its leaders are willing to do so even when such action comes at significant cost to its reputation and the geopolitical stability of the region (ICG 2015: 6-8).

Fewer questions surround the outcome of the factional struggles among Vietnamese political elites with regard to the PRC and its proxies in the South 
China/East Sea. The general consensus is that the "pro-China" faction won, though what it won is not clear. Critics argue that the decision to "back down" - that is, to suppress peaceful anti-China demonstrations, to reemphasize the need for greater "restraint" on all sides, and to not institute arbitral proceedings against the PRC under Annex VII of UNCLOS concerning the legality of the Ushaped line (Gao and Jia 2013) - does not mean that the Chinese government will make concessions to the SRV on other issues, particularly economic ones, in the future (Abuza 2014; Amer 2014). The official statements by both governments that ideological solidarity still exists and mutually beneficial outcomes are still possible is naïve at best according to one Vietnamese analyst. The "friendship," he claims, is completely "illusory" (Hạ Mai 2014).

Alexander Vuving (2014), a scholar at the Asia-Pacific Center for Security Studies, offered a more nuanced interpretation. According to him, the PRC set four preconditions on diplomatic talks regarding the HYSY-981 standoff. The first two - renounce claims to the Paracel Islands and immediately cease naval maneouvers against the Chinese flotilla - were political non-starters. The second two - do not seek a legal ruling on the U-shape line, or involve third parties, especially the United States, in the dispute - were both met. But, as Vuving points out, both concessions are easily "reversible," moreover, other regional actors are likely to begin "to readjust their military postures and foreignpolicy alignments" (Thayer 2014) as a consequence of the PRC's recent actions. Vuving's conclusion, which may or may not be fully correct, is nonetheless consistent with assessements of the SRV's broader A2AD strategy vis-à-vis the PRC.

Security experts do not agree on the precise number of elements, but there is a general consensus that the following three are fundamental to A2AD: 1) pursue a multi-lateral security approach to counter-act the Chinese government's efforts to frame the overlapping territorial disputes as an issue that should be resolved through separate bilateral talks, 2) raise the costs of aggressive unilateral action by signing a series of "strategic/comprehensive partnerships" with key countries (e.g. Japan, India, Russia, and the United states), and 3) modernize the country's own A2AD capabilities (Liu and Sun 2015). Energy security, as it relates to national security more broadly, is a critical though not always explicitly recognized component of the overarching strategy. PetroVietnam's ongoing efforts to increase the number of not yet built energy projects through increased jointventure exploration and production-sharing agreements it has with foreign energy companies, especially state-owned ones, is clearly a part of these A2AD security strategies. Significantly, these agreements are not limited to Vietnam's EEZ. PetroVietnam also conducts exploration activities and extracts oil in coordination with Malaysian and Indonesian SOEs, two countries that also dispute PRC claims to waters that fall within their respective EEZs.

These examples foreground an important paradox. Not yet built energy infrastructure can stabilize as well as destablize security objectives simultaneously. The PRC, for example, submitted a "Good-Neighborliness, Friendship and 
Cooperation Treaty" to ASEAN for consideration in November 2014, several months after the HYSY-981 standoff ended. As part of the Treaty, the PRC offered a package of preferential and special loans, valued at US\$20 billion, to ASEAN on the condition that claimant states settle any territorial disputes with it on a bilateral basis (Webb and Mooney 2014). The network, which will augment the ones the Chinese-led Asian Infrastructure Investment Bank, a multi-lateral international financial institution, is already funding, would obviously increase the costs of challenging Chinese military and economic activities in the South China/East Sea. But the proposed treaty, which is still under discussion, did not dissuade the SRV from reasserting its opposition to the PRC's U-shaped line. The Chinese Ministry of Foreign Affairs issued a position paper in early December 2014 that politely denounced the decision by the Philippines to seek a ruling by the UN Permanent Court of Arbitration on the line (Mincai 2014). The Vietnamese Ministry of Foreign Affairs submitted an official statement several days afterwards requesting that the Tribunal "pay due attention to the legal rights and interests of Viet Nam" when evaluating the case. Chinese Communist Party Politburo Standing Committee Member Yu Zhengseng traveled to Hanoi to meet with senior Party and government officials two weeks later, indicating the seriousness with which the PRC regarded the SRV's request (SRV 2014b).

\section{Conclusion}

The Vietnamese Communist Party held its $12^{\text {th }}$ Congress in January 2016. The impacts of the leadership changes on the future of Sino-Vietnamese relations are not yet clear, and they may not become so until the next territorial crisis. Such a crisis would contribute to a resurgence of maritime nationalism, i.e. popular demands for stronger state action in the South China/East Sea, which would pose a number of problems. The Vietnamese Communist Party, relevant government ministries, and the military did not unite to provide a coherent response to the HYSY-981 standoff due to the ideological factions and competing economic interests within each of them. There is no evidence to suggest that united response would be forthcoming in the event of another crisis, which would adversely affect the legitimacy of the regime. Aggressive action by one or more of the claimant states to consolidate territorial control over contested maritime spaces in the event of such a crisis would almost certainly destabilize the region further as well. At the very least, it would accelerate preemptive action and other A2AD strategies different state actors already use. Stateproxies, such as PetroVietnam, matter for these reasons.

"States" are not unified and coherent entities that think and act like persons; instead, "states" are both more and less than the bureaucratic institutions, discourses, and (un-) official practices that shape our political imaginaries, economic 
possibilities, and everyday realities. Not yet built infrastructure (e.g. offshore pipelines) and the ideological positions that inform their future construction (i.e. the why behind the what) opens up the analytical space to study Vietnamese statehood in a manner traditional approaches do not (MacLean 2013). For example, post-reform (Đối mói i) era studies have largely focused on the effects that market-oriented reforms and good governance initiatives have had upon organizational structures, administrative decision-making, as well as policy formulation and implementation in different sectors (Tran Thi Bich 2014). The literature on the privatization of state-owned enterprises (SOE) is a subset of these overarching topics. The literature details the outcomes the process either has had on service delivery or the impacts it would have on patterns of foreign direct investment if further privatization were to be carried out (Masino 2010). But the literature does not explore how some SOEs serve as proxies and thus form material-semiotic infrastructure of the state. PetroVietnam, while not the primary subject of this essay, figures in it because the company is key element of the government's strategic foreign policy calculations and A2AD strategies.

PetroVietnam's webpage provides an entry point into such an exploration. The rotating banner images on it feature the SOE at constant work. Some offshore rigs operate through the night with flares punctuating the dark sky, while others foreground them against the coming dawn. Meanwhile, smoking refineries onshore busily liquefy natural gas. Taken together, these images convey the same point-namely, PetroVietnam's infrastructure is powering the nation's economy 24/7. PetroVietnam's online maps of oil and gas blocks available for lease as well as planned pipelines to deliver hydrocarbons to onshore processing facilities perform similar future-oriented functions. The maps not only give clear visual form to state claims to maritime territory; they also serve as symbolic "promissory notes" (Hetherington 2014: 196) of returns on investment for "the nation," which in turn reinforce hydrocarbon fantasies of economic progress.

But upon closer examination, the relationship of the SOE to the national economy and thus the country's security is much more complex. SOEs consist of yet more proxies - many of them intertwined with non-state entities. These nested relationships further blur the boundaries between the "public" and the "private" sectors and thus the question of whose interests are to be protected, against what, and with what strategic goals in mind. PetroVietnam is no different; it has six subsidiaries - ranging from hydrocarbon exploration and production to electricity generation and a trading and investment corporation. The SOE has the controlling stake in at least fourteen joint stock corporations and companies. PetroVietnam has also joined with Russia's Gazprom to form a new company: Vietgazprom (PetroVietnam 2015). Many of these proxies-within-proxies do not engage in activities that have foreign policy implications, but some do directly (through existing and not yet built infrastructure) and other do indirectly (financial investments). Tracing these links presents a challenge for the above reasons. So, too, does fierce inter-provincial competition to expand existing facilities and 
to win contracts to develop new ones onshore, what I termed proxy infrastructure (refineries, gas-fired power plants, etc.).

A combined material-semiotic focus (Coole and Frost 2010) on energy infrastructure offers one way to begin to trace these networks of power, the institutional relationships they make possible at multiple scales, and the effect both have upon the geopolitics of the South China/East Sea. These processes are not limited to it, however. Similar dynamics are in play throughout the five great maritime basins of the Indo-Pacific (McDevitt, Fravel, and Stern 2013). Boyer refers to these dynamics as energo-power because they draw attention to the multiple ways "energic forces [e.g. oil, gas, and electricity] and the infrastructures [they require] interrelate with institutions and ideations of political power" (2014: 209). Planned but not yet built infrastructure provides a heretofore underutilized way to understand these interrelations and the ideations (the why behind the what) that animate them. Closer attention to imagined infrastructure, the anxieties connected to them, and actions they engender thus promise new insights into Vietnamese statehood, planned efforts to materialize the "nation" offshore, and the implications both have for the Sino-Vietnamese territorial disputes more generally.

\section{References}

Abuza, Zachary. 2014. Vietnam buckles under Chinese pressure. Asia Times Online, 29 July 2014, available at http://www.atimes.com/atimes/Southeast_Asia/SEA-01290714.html (accessed 30 March 2015).

Amer, Ramses. 2014. China, Vietnam, and the South China Sea: disputes and dispute management. Ocean Development \& International Law 45(1), 17-40.

Anand, Nikhil. 2012. Municipal disconnect: on abject water and its urban infrastructures. Ethnography 13(4), 487-509.

Association of Southeast Asian Nations and the People's Republic of China. 2002. Declaration on the Conduct of Parties in the South China Sea, available at http://www. asean.org/news/item/declaration-on-the-conduct-of-parties-in-the-south-china-sea (accessed 20 November 2015).

Bateman, Sam and Ralf Emmers, eds. 2009. Security and international politics in the South China Sea: towards a cooperative management regime. London: Routledge.

Beckman, Robert. 2014. Large-scale reclamation projects in the South China Sea: China and international law. Singapore: RSIS Commentary no. 213.

Boyer, Dominic. 2014. Energo power: an introduction. Anthropological Quarterly 87(2), $1-37$.

Buszynski, Leszek. 2012. The South China Sea: oil, maritime claims, and US-China strategic rivalry. The Washington Quarterly 35(2), 139-156.

Buszynski, Lesek and Christopher Roberts, eds. 2014. The South China Sea maritime dispute: political, legal, and regional perspectives. London: Routledge.

Callahan, William. 2009. The cartography of national humiliation and the emergence of China's geobody. Public Culture 21(1), 141-73.

Chevron, 2007. Chevron to partner with CNPC on major gas project in China, 18 December, available at http:/www.chevron.com/chevron/pressreleases/article/ 
12182007_chevrontopartnerwithcnpconmajorgasprojectinchina.news (accessed on 25 March 2015).

Coleman, Leo. 2014. Infrastructure and interpretation: meters, dams, and state imagination in Scotland and India. American Ethnologist 41(3), 547-472.

Collier, Stephen and Andrew Lakoff. 2008. The vulnerability of vital systems: how "critical infrastructure" became a security problem. The politics of securing the homeland: critical infrastructure, risk, and securitization, eds. M.D. Cavelty, K.S. Kristensen, pp. 40-62. New York: Routledge.

Coole, Diana, and Samantha Frost (eds.). 2010. New materialisms: ontology, agency, and politics. Durham, N.C.: Duke University Press.

Cunningham, Nick. 2014. Why oil and gas in the South China Sea won't be developed. Oilprice (17 July).

Dou, Eva and Richard Paddock. 2014. Behind Vietnam's anti-China riots, a tinderbox of wider grievances. The Wall Street Journal (17 June).

Downs, Erica. 2014. Business and politics in the South China Sea: explaining HYSY-981's foray into disputed waters. China Brief XIV(12), 6-7.

Dupuy, Florian and Pierre Marie Dupuy. 2013. A legal analysis of China's historic rights claim in the South China Sea. The American Journal of International Law 107(1), $124-141$.

Elferink, Alex G. Oude. 2001. The islands in the South China Sea: how does their presence limit the extent of the high seas and the area and the maritime zones of the mainland coasts? Ocean Development \& International Law 32(2), 169-190.

Gjetnes, Marius. 2001. The Spratlys: are they rocks or islands? Ocean Development of International Law (32), 191-204.

Gao, Zhiguo, and Bing Bing Jia. 2013. The nine-dash line in the South China Sea: history, status, and implications. American Journal of International Law 107(1), 98-124.

Hạ Mai. 2014. Thủ Tướng có thụ̉c sụ̉ không màng ‘hưu nghị viển vông’ [In reality, the Prime Minister is not interested in utopian friendship], available at http://www. viet-studies.info/kinhte/HaMai_ThuTuongHuuNghiVienVong.htm (accessed on 22 June 2014).

Hai Tien Le. 2012. Policy suggestions for the initial development of Vietnam's gas industry. Washington D.C.: Brookings Institution.

Hardy, James, and Sean, O’Conner. 2014. China building airstrip-capable island on Fiery Cross Reef. IHS Jane's Defense Weekly (20 November).

Hetherington, Kregg. 2014. Waiting for the surveyor: Development promises and the temporality of infrastructure. The Journal of Latin American and Caribbean Anthropology 19(2), 195-211.

Huong Le Thu. 2014. The anti-Chinese riots in Vietnam: responses from the ground. Singapore: ISEAS Perspective No. 32.

Indo-Pacific Review. 2014. Fear us: military expenditures in Southeast Asia, available at http://www.indopacificreview.com/military-expenditures-southeast-asia/\#sthash.QZr6x TNP.dpbs (accessed on 25 March 2015).

International Crisis Group. 2015. Stirring up the South China Sea (III): a fleeting opportunity for calm. Brussels: ICG.

International Union for Conservation of Nature. 2012. Exclusive Economic Zone, 25 October 2012, posted by IUCN, available at http://iucn.org/about/union/secretariat/ offices/iucnmed/iucn_med_programme/marine_programme/governance/glossary/? 11323 (accessed on 5 March 2015).

Jennings, Ralph. 2014. Pixel by pixel, Taiwan maps out claims to contested South China Sea," Christian Science Monitor (23 September). 
Keyuan, Zou. 2012. China's U-shaped line in the South China Sea revisited. Ocean Development \& International Law 43(1), 18-34.

Larkin, Brian. 2013. The politics and poetics of infrastructure. Annual Review of Anthropology (42), 327-343.

Larson, Christina. 2015. China's island building is destroying reefs. Science 349(6255), 143.

Le Hai Binh. 2015. Remarks on the South China Sea arbitration case, posted by Ministry of Foreign Affairs, 18 March, http://www.mofa.gov.vn/en/tt_baochi/ pbnfn/ns141212143709/view (accessed on 18 March 2015).

Le Mière, Christian. 2012. Anti-access/area denial and the South China Sea. Paper presented at the Conference on "The South China Sea: Cooperation for regional security and development," Ho Chi Minh City, Vietnam, 19-21 November 2012.

Liu, Ruonan and Xuefeng Sun. 2015. Regime security first: explaining Vietnam's security policies towards the United States and China (1992-2012). The Pacific Review 28(5), $1-24$.

MacLean, Ken. 2014. "From land to water: fixing fluid frontiers and the limits of sovereign authority in the South China/Eastern Sea," In Forging the fiery frontier: two millennia of China's encounters on the south and the southwest, eds. John Whitmore and James Anderson, pp. 370-394. Leiden: Brill.

MacLean, Ken. 2013. The government of mistrust: illegibility and bureaucratic power in socialist Vietnam. Madison: University of Wisconsin Press.

MacLean, Ken. 2008. "In search of kilometer zero: digital archives, technological revisionism, and the Sino-Vietnamese border," Comparative Studies in Society and History 50(4), 862-894.

Masino, Pietro. 2010. Vietnam between developmental state and neoliberalism: the case of the industrial sector. Naples: University of Naples.

McDevitt, Micheal, Taylor Fravel, and Lewis Stern. 2013. The long littoral project: South China Sea - a maritime perspective on Indo-Pacific security. Arlington, VA: CNA Analysis and Solutions.

Mincai, Yu. 2014. China's responses to the compulsory arbitration on the South China Sea dispute: legal effects and policy options. Ocean Development \& International Law 45(1), 1-16.

Murphy, Martin. 2013. Deepwater oil rigs as strategic weapons. Naval War College Review 66(2), 110-114.

Nguyễn Hồng Thảo. 2005. "Maritime delimitation and fishery cooperation in the Tonkin Gulf," Ocean Development \& International Law 36, 25-44.

Nguyễn Tấn Dũng. 2007. Phê duyệt chiến lược phát triển năng lượng quốc gia Việt Nam đến năm 2020, tầm nhìn đến năm 2050, số 1855/QĐ-TTg (27 December) [Prime Minister, Decision No. 1855/QD-TTg ratifying Vietnam's national energy development strategy up to 2020 and vision to 2050].

People's Republic of China. 1996. Declaration of the government of the People's Republic of China on the baselines of the territorial sea. Beijing: PRC.

People's Republic China. 2014. The operation of the HYSY-981 drilling rig: Vietnam's provocation and China's position, 8 June, posted by the Ministry of Foreign Affairs, available at http://www.fmprc.gov.cn/mfa_eng/zxxx_662805/t1163264.shtml (accessed on 7 March 2015).

PetroVietnam Drilling News. 2012. PetroVietnam requests CNOOC to stop erroneous bid invitation, 5 July, available at http://english.pvn.vn/?portal=news\&page=detail\& category_id=95\&id=3667 (accessed on 28 March 2015). 
Platts, "Vietnam’s PV gas secures $\$ 280$ mil loan to build gas pipeline (3 July), available at http://www.platts.com/latest-news/natural-gas/hanoi/vietnams-pv-gas-secures-280-milloan-to-build-26826638 (accessed 18 March 2015).

Power, Michael. 2007. Organized uncertainty: designing a world of risk management. Oxford: Oxford University.

Roberts, Dexter. 2014. China state enterprises told to stop investing in Vietnam. Bloomberg Business (9 June), available at http://www.bloomberg.com/bw/articles/2014-0609/chinas-state-enterprises-told-to-stop-investing-in-vietnam (accessed on 15 March 2015).

Socialist Republic of Viet Nam. 2014a. Contents of the international press conference on developments in the East Sea, 7 June, posted by the Permanent Mission of the Socialist Republic of Vietnam to the United Nations, available http://www.vietnam-un. org/en/news.php?cid=3\&id=230 (accessed on 7 March 2015).

Socialist Republic of Vietnam. 2014b. Thủ tướng chỉ đạo đảm bảo an ninh trật tụ̉ [Prime Minister Guides and Guarantees Security and Order], 15 May 2014, posted by VGP News, available at http://baodientu.chinhphu.vn/Tin-noi-bat/Cong-dien-cua-Thutuong-Chinh-phu-ve-dam-bao-an-ninh-trattu/199262.vgp (accessed 15 March 2015).

Socialist Republic of Viet Nam. 2009. Submission to the commission on the limits of the continental shelf (CLCS) beyond 200 nautical miles from the baselines. Hanoi: Socialist Republic of Viet Nam.

Shoji, Tomotaka. 2014. Briefing memo: Vietnam and China over the South China Sea: the confrontation proceeds towards a new phase. Seoul: The National Institute for Defense Studies.

Storey, Ian. 2014. The Sino-Vietnamese oil rig crisis: implications for the South China Sea dispute. Singapore: ISEAS Perspective no. 52.

Thayer, Carl. 2014. 4 reasons China removed oil rig HYSY-981 sooner than later. The Diplomat (22 July).

The Economist. 2015. Oil on troubled waters, 24 January, available at http://www. economist.com/news/asia/21640403-two-case-studies-disputed-sea-oil-troubled-waters (accessed on 23 March 2015).

Tran Thi Bich, 2014. The cycle of transparency, accountability, corruption, and administrative performance: evidence from Vietnam. Journal of Economics and Development 16(3), 32-48.

Tuẩn Khanh. 2014. Đi giưa dòng bạo động [Amidst the Stream of Violence], available at https://nhacsituankhanh.wordpress.com/2014/05/15/di-giua-dong-bao-dong-p-1/ (accessed on 15 March 2015).

United Nations. 1993. United Nations Convention on the Law of the Sea, available at http://www.un.org/depts/los/convention_agreements/texts/unclos/unclos_e.pdf (accessed on 20 November 2015).

United States Energy Information Administration. 2014. Kuwait, 24 October, available at http://www.eia.gov/countries/cab.cfm?fips=ku (accessed on 15 March 2015).

Vuving, Alexander. 2014. Did China blink in the South China Sea? The National Interest. 27 July, available at http://nationalinterest.org/feature/did-china-blink-the-southchina-sea-10956 (accessed on 28 March 2015).

Wanichakul, Thongchai. 1997. Siam mapped: a history of the geo-body of the nation. Honolulu: University of Hawai'i Press.

Want China Times. 2014. Beijing to use floating docks for South China Sea reclamation. 30 October, available at http://www.wantchinatimes.com/news-subclass-cnt.aspx? id=20141030000125\&cid=1101 (accessed 18 March 2015). 
Webb, Simon and Paul Mooney. 2014. China offers ASEAN friendship, loans as South China Sea tension bubbles. Reuters (13 November).

$\mathrm{Xu}$ Liangbin, Jiang Shiquan, and Zhuo Jianliang. 2013. The challenges and solutions for deep water drilling in the South China Sea. Beijing: CNOOC Research Institute. 